Samuel: Peningkatan Pengetahuan dan Sikap Ibu

\title{
Peningkatan Pengetahuan dan Sikap Ibu Tentang Imunisasi dengan Pendekatan Promosi Kesehatan Tentang Imuniasi Dasar
}

\author{
Samuel M. Simanjuntak, Indah Nurnisa \\ Fakultas Ilmu Keperawatan, Universitas Advent Indonesia \\ Email: smsimanjuntak@unai.edu
}

\begin{abstract}
Abstrak
Angka capaian imunisasi dasar di Bandung Barat termasuk dalam 10 kabupaten di Jawa Barat dengan pencapaian yang terendah. Edukasi kepada ibu-ibu dengan beragam pendekatan masih sangat diperlukan. Tujuan dari pengabdian masyarakat ini adalah untuk menerapkan dan mengevaluasi pendekatan promosi kesehatan tentang imunisasi dasar dalam meningkatkan pengetahuan dan sikap ibu terhadap imunisasi di RW.06 desa Sukajaya. Metode yang digunakan dalam pengabdian masyarakat ini adalah dengan pemberian promosi kesehatan imunisasi dasar kepada 60 ibu-ibu yang memiliki anak Batita. Sebelum penyuluhan pengetahuan dan sikap ibu dikaji dengan pengisian kuesioner yang kemudian dikaji ulang saat setelah pelaksanaan penyuluhan. Hasil analisis data menunjukkan bahwa ada perbedaan yang signifikan dalam pengetahuan dan sikap ibu tentang imunisasi dasar pada batita antara sebelum dan sesudah promosi kesehatan tentang imunisasi di RW.06 desa Sukajaya dengan p value $\leq 0,05$. Kesimpulan dari penelitian ini adalah penyuluhan tentang imunisasi dasar pada batita kepada para ibu secara signifikan meningkatkan pengetahuan dan sikap ibu terhadap imunisasi dasar. Dari hasil tersebut peneliti menyarankan kepada perawat atau tim kesehatan terkait untuk melakukan promosi kesehatan tentang imunisasi dasar secara berkala kepada masyarakat khususnya ibu-ibu yang memiliki Batita untuk meningkatkan derajat kesehatan anak-anak di kabupaten Bandung Barat dan di Indonesia secara lebih luas.
\end{abstract}

Kata kunci : Imunisasi dasar, Pengetahuan, promosi kesehatan, sikap

\begin{abstract}
Based on the interview with four mothers who had children with age under three years old in Sukajaya village, it was found that only one mother understood about the importance of basic immunization and the basic immunization schedule, one mother just knew about the importance of immunization but did not know the schedule for the immunization. and two more mothers did not know about the importance of immunization and the schedule of it. The purpose of this study was to determine the influence of the health promotion of toddlers' basic immunization towards the mothers' knowledge and attitudes about the immunization at RW.06 Sukajaya village. The method used in this study was quasy experimental with one group pre-test post-test without control. The data gathered in this study were obtained from questionnaire filled by the respondents and analyzed by using SPSS. The results of data analysis showed that there were significant differences regarding the mothers' knowledge about toddlers basic immunization before and after the health promotion of the immunization at RW.06 Sukajaya village with $p$ value $<0.05$, and there were significant differences towards the mothers' attitudes regarding the toddlers' basic immunization before and after the health promotion of the immunization at RW.06 Sukajaya village with $p$ value $=$ 0.00. The conclusion of this study was the counseling given to the mothers regarding the toddlers' basic immunization had significantly increased the mothers' knowledge and attitudes. From these results, the researcher suggested that nurses or related health workers need to conduct the health promotions on basic immunization on a regular basis to the public, especially mothers with toddlers to improve the health standard of Indonesian children.
\end{abstract}

Keywords: Basic immunization, knowledge, attitude, health promotion 
Samuel: Peningkatan Pengetahuan dan Sikap Ibu

\section{Pendahuluan}

Cakupan imuniasi di Indonesia terus meningkat dan hingga tahun 2016 mencapai 79\%. Cakupan imunisasi anak di negara-negara WHO (World Health Organization) masih mencapai 85\% dari bayi di seluruh dunia telah mendapat imunisasi dan masih terdapat $19,9 \%$ juta bayi dan anakanak belum sepenuhnya mendapatkan vaksinasi dan tetap beresiko terkena penyakit (WHO Global Immunization Data, 2017).

Imunisasi adalah salah satu jenis usaha memberikan kekebalan kepada anak dengan memasukkan vaksin ke dalam tubuh guna membuat zat anti untuk mencegah terhadap penyakit tertentu (Mahayu, 2014). World Health Organization (WHO) mulai menetapkan program imuniasi sebagai upaya global dengan Expanded Program on Imunization (EPI) pada tahun 1974, yang disolusikan oleh World Health Assembly (WHA). Terobosan ini menempatkan EPI sebagai komponen penting pelayanan kesehatan ibu dan anak, khususnya dalam pelayanan kesehatan primer. Pada tahun 1981 mulai dilakukan imunisasi polio, tahun 1982 imunisasi campak, dan tahun 1997 imunisasi hepatitis mulai dilakukan. Imunisasi secara nyata terbukti telah menyelamatkan jutaan nyawa dan secara luas diakui sebagai salah satu intervensi kesehatan yang paling berhasil dan efektif (hemat biaya) di dunia. Namun, masih ada lebih dari 19 juta anak di dunia yang tidak divaksinasi atau vaksinasinya tidak lengkap, yang membuat mereka sangat berisiko untuk menderita penyakit-penyakit yang berpotensi mematikan (IDAI, 2018).

Kesehatan anak di dunia khususnya di negara yang sedang berkembang masih tergolong rendah. Data global menunjukkan bahwa masih ada 11 juta anak berusia di bawah 5 tahun meninggal setiap tahunnya. Data tersebut menambahkan bahwa 4 juta dari anak-anak tersebut masih berusia di bawah 1 bulan, sedang jutaan lainnya hidup dengan gangguan kesehatan seperti menderita penyakit polio,diare, cacat bawaan dan perkembangan seperti lambat berjalan dan bicara(Pratiwi, 2015). Masih besarnya angka kematian anak ini umumnya dipicu oleh faktor yang masih bisa dicegah, seperti kurang gizi dan infeksi misalnya infeksi saluran pernafasan dan infeksi saluran pencernaan.

Saat ini di Indonesia masih ada anak-anak yang belum mendapatkan imunisasi secara lengkap bahkan tidak pernah mendapatkan imunisasi sedari lahir. Hal tersebut menyebabkan mereka akan mudah tertular penyakit berbahaya karena tidak adanya kekebalan terhadap penyakit tersebut. Data dari Direktorat Pencegahan dan Pengendalian Penyakit, Kementerian 
Kesehatan (Kemenkes) RI menunjukkan sejak 2014-2016, terhitung sekitar 1,7 juta anak belum mendapatkan imunisasi atau belum lengkap status imunisasinya. Angka cakupan imunisasi di Indonesia rata-rata 91,12 persen, dan masih ada di beberapa daerah cakupan yang relatif rendahseperti di Kalimantan Utara. Ada sekitar 2.400 anak Indonesia meninggal setiap hari termasuk yang meninggal karena penyakit yang seharusnya dapat dicegah dengan imunisasi contohnya tuberculosis, campak, pertussis, difteri, dan tetanus, merupakan tragedi yang mengejutkan dan tidak seharusnya terjadi.

Hasil Survei dan Demografi Kesehatan Indonesia (SDKI) menunjukan bahwa angka kematian anak di Indonesia sebesar 34 per 1000 kelahiran hidup. Angka ini lebih rendah dibandingkan dengan angka kematian anak pada tahun 2002-2003 yang mencapai 35 per 1000 kelahiran hidup. Angka kematian anak pada tahun 2015 diharapkan mencapai 23 per 1000 kelahiran hidup. Dengan demikian, imunisasi adalah upaya efektif untuk menekan angka kematian anak (Kepmenkes, 2010).

Cakupan desa/kelurahan Universal Child Imunization (UCI) di provinsi Jawa Barat sejak tahun 2008 sampai dengan 2016 cenderung meningkat dari $66 \%$ pada tahun 2008 menjadi 92\% pada tahun 2016, jika dibandingkan dengan tahun 2015 naik 1,5 poin secara rinci perKabupaten/Kota. Pada tahun 2016 cakupan desa/kelurahan UCI, sebanyak 5.483 desa/kelurahan dari 5.962 yang ada di Jawa Barat (92\%), tersebar di 27 Kabupaten/Kota dengan cakupan antara 75\%-100\%, Kab/Kota yang cakupannya masih dibawah rata rata Provinsi adalah Kab Bandung, Kab Garut, Kota Cimahi, Kab Cirebon, Kab Cianjur, Kab Ciamis, Kota Cirebon, Kab Subang dan Kab Kuningan (Dinas kesehatan, 2016). Namun demikian, di Kabupaten Bandung Barat kasus campak masih ditemukan yaitu pada tahun 2015, sebanyak tujuh orang yang terkena campak, hal ini karena masih kurangnya sosialisasi dan kepatuhan ibu untuk melaksanakan imunisasi. Sesuai dengan peraturan Menteri Kesehatan nomor 42 tahun 2013 yang menyatakan tentang penyelenggaraan imunisasi bahwa untuk meningkatkan derajat kesehatan masyarakat dan mempertahankan status kesehatan seluruh rakyat diperlukan tindakan imunisasi sebagai tindakan preventif.

Usaha-usaha yang dilakukan dinas kesehatan masih banyak mengalami kendala diantaranya pengetahuan orang tua, kesibukan orang tua, kurang sosialisasi dari pemerintah serta budaya menjadi faktor yang mempengaruhi kepatuhan orang tua untuk memberikan imunisasi 
pada bayinya. Sehingga imunisasi menjadi hal yang kurang penting bagi masyarakat terutama bagi ibu, karena ibu yang berperan besar dalam merawat anak dan mengambil keputusan untuk kelengkapan imunisasi anak (Arifin, 2011).

Berdasarkan penelitian yang dilakukan Fredrickson, et al. (2004), menunjukan bahwa orang tua menolak untuk memberikan imunisasi kepada anaknya dikarenakan kurangnya pemahaman orang tua tentang pentingnya imunisasi bagi anak. Orang tua merasa khawatir mengenai efek samping yang ditimbulkan setelah imunisasi sebab orang tua takut anaknya sakit.

Hasil survey awal yang penulis lakukan di desa Sukajaya, penulis mewawancarai empat orang ibu yang mempunyai anak di bawah usia tiga tahun, ternyata satu orang ibu yang mengerti tentang pentingnya imunisasi dasar dan jadwal pemberian imunisasi dasar, satu orang ibu hanya mengetahui tentang pentingnya imunisasi tetapi tidak mengetahui jadwal pemberian imunisasi, dan dua orang lagi tidak mengetahui tentang pentingnya imunisasi dan jadwal pemberiannya.

Macintosh, Eden, Luthy, dan Schouten (2017) menekankan bahwa perawat di seluruh dunia dapat berperan besar dalam meningkatkan partisipasi masyarakat khususnya ibu-ibu dengan Batita dalam pemberian imunisasi dasar. Para perawat dapat melakukan perannya dalam pelaksanaan program-program pendidikan dan penjangkauan bekerjasama dengan organisasi local dan global memfasilitasi keluarga kepada perolehan imunisasi. Perawat dapat menumbuhkan dan meningkatkan rasa percaya dan pengetahuan komunitas setempat terhadap imunisasi. Perawat memiliki pengaruh yang besar dalam perjuangan meningkatkan cakupan imunisasi yang merupakan aspek sangat vital dalam upaya pencegahan penyakit dan promosi kesehatan global.

\section{Metode}

Metode yang digunakan dalam pengabdian masyarakat ini adalah dengan pemberian promosi kesehatan tentang imunisasi dasar kepada 60 ibu yang memiliki Batita. Lokasi pengabdian masyarakat dilakukan di RW.06 desa Sukajaya kecamatan Lembang, kabupaten Bandung Barat pada tanggal 2 Januari 2019. Target populasi dalam pengabdian masyarakat ini adalah ibu yang memiliki anak usia di bawah 3 tahun yang merupakan bagian dari kabupaten dengan capaian imunisasi yang rendah (83.23\%) di Jawa Barat(Pos Kota, 2017). Peserta yang berpastisipasi dalam pengabdian masyarakat ini diundang melalui bantuan kader kesehatan desa yang juga 
berprofesi sebagai bidan desa. Peserta yang hadir datang secara sukarela dan bersedia mengikuti promosi kesehatan imunisasi dasar.

Proses promosi kesehatan dilakukan dalam enam (6) sesi yaitu diawali dengan sesi pembukaan dimana acara dibuka oleh kader setempat bersama-sama dengan ketua RW. Setelah sambutan pembukaan, selanjutnya pada sesi kedua ulama setempat yaitu seorang Ustad memimpin doa dan kemudian dilanjutkan dengan memberikan dakwah tentang "Pentingnya kesehatan anak dan peran ibu dalam imunisasi berdasarkan pandangan Islami."

Tim penyuluh mengawali sesi ketiga dengan perkenalan dan selanjutnya menjelaskan secara terperinci tujuan, manfaat dan proses dari promosi kesehatan kepada ibu-ibu. Ketua tim kemudian memohon kesediaan berpartisipasi dalam program promosi kesehatan imunisasi serta evaluasinya. Pada sesi keempat, tim memberikan lembar kaji pengetahuan dan sikap tengtang imunisasi dasar kepada semua ibu-ibu dan memberikan waktu 15 menit untuk mengisinya. Setelah lembar kaji dikumpulkan maka materi tentang imunisasipun dipaparkan pada sesi kelima. Materi promosi kesehatan yang diberikan diadopsi dari bahan informasi seputar imunisasi dari Dinas kesehatan (Dinas Kesehatan Provinsi Jawa Barat, 2014) yang mencakup:

1. Penyakit-penyakit yang dapat dicegah dengan imunisasi yaitu Difteri, pertussis, tetanus, tuberculosis (TBC), campak, polio dan hepatitis B.

2. Jenis-jenis vaksin

3. Jadwal pemberian imunisasi pada bayi

Setelah seluruh materi diberikan maka lembar kaji pengetahuan dan sikap terhadap imunisasi diberikan kembali. Pada sesi keenam kader kembali mengambil alih acara dan memberikan kata penutup sebagai akhir dari seluruh sesi promosi kesehatan.

\section{Hasil}

\section{Karakteristik Usia dan Latar Pendidikan Ibu}

Tabel 1 menunjukan bahwa kelompok usia ibu-ibu 21-25 tahun berjumlah 23 orang (38.3\%), kelompok usia 16-20 dengan jumlah 14 orang (23.3\%), kelompok usia 26-30 berjumlah 11 orang (18.3\%), kelompok usia 36-40 berjumlah 7 orang (11.7\%), kelompok usia 31-35 berjumlah 4 orang (6.7\%), dan kelompok usia 41-45 berjumlah 1 orang (1.7\%). 
Samuel: Peningkatan Pengetahuan dan Sikap Ibu

Tabel 1. Gambaran Usia

\begin{tabular}{ccc}
\hline Kelompok Usia & Frequency & Percent \\
\hline $\mathbf{1 6 - 2 0}$ & 14 & 23.3 \\
\hline $\mathbf{2 1 - 2 5}$ & 23 & 38.3 \\
\hline $\mathbf{2 6 - 3 0}$ & 11 & 18.3 \\
\hline $\mathbf{3 1 - 3 5}$ & 4 & 6.7 \\
\hline $\mathbf{3 6 - 4 0}$ & 7 & 11.7 \\
\hline $\mathbf{4 1 - 4 5}$ & 1 & 1.7 \\
\hline Total & 60 & 100.0 \\
\hline
\end{tabular}

Pada tabel 2 menunjukan bahwa pendidikan terakhir responden dengan jumlah dan persentase tertinggi adalah Sekolah Menengah Atas yaitu 32 orang (53.3\%), kemudian Sekolah Menengah Pertama dan setara berjumlah 16 orang (26.7\%), Sekolah Dasar dan setara berjumlah 11 orang (18.3\%), sedangkan responden dengan pendidikan terakhir Sarjana berjumlah 1 orang $(1.7 \%)$.

Tabel 2. Gambaran Pendidikan Terakhir

\begin{tabular}{ccc}
\hline Jenjang Pendidikan & Frequency & Percent \\
\hline SD/Setara & 11 & 18.3 \\
\hline SMP/Setara & 16 & 26.7 \\
\hline SMA/Setara & 32 & 53.3 \\
\hline Sarjana & 1 & 1.7 \\
\hline Total & 60 & 100.0
\end{tabular}

\section{Karakteristik Pekerjaan Ibu-ibu dan Suami}

Tabel 3 di bawah menunjukan bahwa pekerjan sebagai Ibu Rumah Tangga berjumlah 53 orang (88.3\%), sebagai Wiraswata berjumlah 6 orang (10.0\%), dan ibu-ibu yang bekerja sebagai Petani yang berjumlah 1 orang (1.7\%). Tabel yang sama menunjukan bahwa pekerjaan suami terbanyak adalah sebagai Wiraswasta 45 orang (75.0\%), Bertani berjumlah 11 orang (18.3\%), Beternak berjumlah 2 orang (3.3\%), dan sebagai Buruh berjumlah 2 orang (3.3\%). 
Tabel 3. Gambaran Pekerjaan ibu dan suami

\begin{tabular}{lcc}
\hline Pekerjaan Ibu & Frequency & Percent \\
\hline $\begin{array}{c}\text { Ibu rumah } \\
\text { tangga }\end{array}$ & 53 & 88.3 \\
\hline \multicolumn{1}{c}{ Wiraswasta } & 6 & 10.0 \\
\hline \multicolumn{1}{c}{ Petani } & 1 & 1.7 \\
\hline \multicolumn{1}{c}{ Total } & 60 & 100.0 \\
\hline Pekerjaan Suami & Frequency & Percent \\
\hline Wiraswasta & 45 & 75.00 \\
\hline Bertani & 11 & 18.3 \\
\hline Beternak & 2 & 3.3 \\
\hline Buruh & 2 & 3.3 \\
\hline Total & $\mathbf{6 0}$ & $\mathbf{1 0 0 . 0}$ \\
\hline
\end{tabular}

\section{Karakteristik Jumlah Anak Dalam Keluarga}

Pada tabel 4 terefleksi bahwa jumlah anak dalam keluarga ibu-ibu peserta promosi kesehatan adalah satu orang anak berjumlah 28 orang (46.7\%), yang memiliki dua orang anak berjumlah 17 orang (28.3\%), tiga orang anak berjumlah 11 orang (18.3\%), dan yang memiliki empat orang anak berjumlah 4 orang $(6.7 \%)$.

Tabel 4. Gambaran Jumlah Anak Dalam Keluarga

\begin{tabular}{ccc}
\hline Jumlah Anak & Frequency & Percent \\
\hline Anak 1 & 28 & 46.7 \\
Anak 2 & 17 & 28.3 \\
Anak 3 & 11 & 18.3 \\
Anak 4 & 4 & 6.7 \\
Total & 60 & 100.0 \\
\hline
\end{tabular}

\section{Karakteristik Imunisasi yang Sudah Diterima Anak dan Tempat Imunisasi}

Hasil perolehan data pada tabel 5 di bawah menunjukan bahwa jenis imunisasi yang sudah diterima anak yang tertinggi yakni BCG, DPT, Polio, Campak, dan Hepatitis B berjumlah 25 orang $(41.7 \%)$, BCG, DPT, Polio, dan Hepatitis B berjumlah 9 orang $(15.00 \%)$, imunisasi BCG, DPT, Polio, Campak berjumlah 9 orang (15.00\%), imunisasi DPT berjumlah 7 orang 
Samuel: Peningkatan Pengetahuan dan Sikap Ibu

(11.7\%), imunisasi BCG dan imunisasi Polio berjumlah 4 orang (6.7\%), imunisasi Campak berjumlah 4 orang (6.7\%), kemudian imunisasi Polio berjumlah 2 orang (3.3\%). Ini menunjukan bahwa lebih dari separuh responden belum mengimunisasikan anaknya secara lengkap yaitu sebanyak 58,3\%. Tabel 5 lebih lanjut menunjukan bahwa tempat anak memperoleh imunisasi yakni di praktek Bidan berjumlah 29 orang (48.3\%), diikuti Posyandu 23 orang (38.3\%), kemudian Puskesmas 8 orang (13.3\%).

Tabel 5. Gambaran Imunisasi yang Sudah Diterima Anak dan Tempat Imunisasi

\begin{tabular}{ccc}
\hline Jenis Imunisasi & Frequency & Percent \\
\hline DPT & 7 & 11.7 \\
Polio & 2 & 3.3 \\
Campak & 4 & 6.7 \\
BCG, DPT, Polio, & 9 & 15.0 \\
HepB & & \\
BCG, DPT, Polio, & 9 & 15.0 \\
$\quad$ Campak & & \\
BCG dan Polio & 4 & 6.7 \\
BCG, DPT, Polio, & 25 & 41.7 \\
Campak dan HepB & & \\
Total & 60 & 100.0 \\
Tempat Imunisasi & & \\
Bidan & Frequency & 48.3 \\
Posyandu & 29 & 38.3 \\
Puskesmas & 23 & 13.3 \\
$\quad$ Total & 8 & 100.0 \\
\hline
\end{tabular}

\section{Gambaran Pengetahuan dan Sikap Ibu Tentang Imunisasi Saat Sebelum dan Setelah Promosi Kesehatan}

Tabel 6 menunjukkan bahwa rerata tingkat pengetahuan ibu sebelum promosi kesehatan tentang imunisasi adalah $62.16 \%$ yang termasuk ke dalam kategori pengetahuan kurang. Pengetahuan ibu sesudah promosi kesehatan tentang imunisasi dasar memiliki hasil rerata 92.26. Berarti jawaban tersebut masuk ke dalam kategori pengetahuan baik. Pada tabel 6 terlihat juga bahwa pengetahuan ibu tentang imunisasi dasar sebelum dan sesudah promosi kesehatan berbeda secara signifikan dengan nilai $p<0,05$. Hasil tersebut menunjukkan bahwa terdapat perbedaan 
Samuel: Peningkatan Pengetahuan dan Sikap Ibu

dalam pengetahuan ibu tentang imunisasi dasar pada batita antara sebelum dan sesudah promosi kesehatan.

Tabel 6. Gambaran pengetahuan ibu sebelum dan sesudah promosi kesehatan

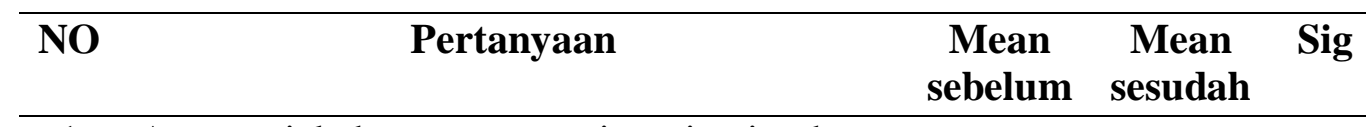

1. Apa sajakah program imunisasi dasar $\begin{array}{llll}\text { lengkap untuk anak yang ibu ketahui? } & 75.00 \quad 100.0 \quad .000\end{array}$

2. Penyakit apa yang dapat dicegah dengan pemberian imunisasi BCG pada anak?

$51.67 \quad 98.33 \quad .000$

3. Berapa kali imunisasi BCG harus diberikan pada anak?

$56.67 \quad 100.0 \quad .000$

4. Kapan waktu yang tepat untuk pemberian imunisasi BCG pada anak?

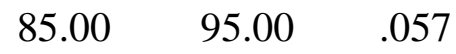

5. Penyakit apa saja yang dapat dicegah dengan pemberian imunisasi Hepatitis B $78.33 \quad 85.00$ pada anak?

$85.00 \quad 95.00 \quad .057$

6. Berapa kali imunisasi Hepatitis B harus diberikan pada anak?

$20.00 \quad 96.67 \quad .000$

7. Kapan waktu yang tepat untuk pemberian imunisasi Hepatitis B kepada anak?

$56.67 \quad 96.67 \quad .000$

8. Penyakit apa yang dapat dicegah dengan pemberian imunisasi DPT pada anak?

$76.67 \quad 88.33 \quad .070$

9. Berapa kali imunisasi Combo DPT-HB harus diberikan pada anak?

$48.33 \quad 95.00 \quad .000$

10. Imunisasi Combo DPT-HB diberikan pada saat usia anak?

$56.67 \quad 98.33 \quad .000$

11. Penyakit apa yang dapat dicegah dengan pemberian imunisasi Polio pada anak?

$86.67 \quad 100.0 \quad .004$

12. Berapa kali imunisasi Polio harus diberikan pada anak?

$35.00 \quad 98.33 \quad .000$ 
Samuel: Peningkatan Pengetahuan dan Sikap Ibu

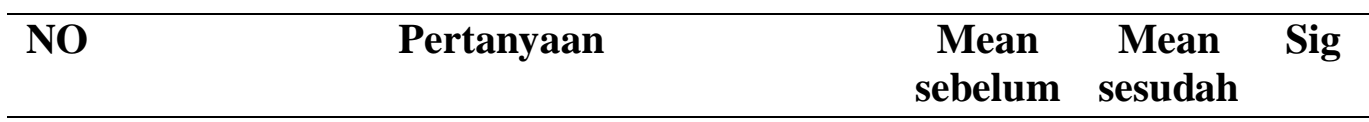

13. Kapan waktu yang tepat untuk pemberian imunisasi Polio kepada anak?

$\begin{array}{lll}55.00 & 98.33 \quad .000\end{array}$

14. Penyakit apa yang dapat dicegah dengan pemberian imunisasi Campak pada anak?

$\begin{array}{lll}63.33 & 96.67 \quad .000\end{array}$

15. Berapa kali imunisasi campak harus diberikan kepada anak?

$\begin{array}{lll}63.33 & 96.67 \quad .000\end{array}$

16. Imunisasi campak diberikan pada saat usia anak?

$51.67 \quad 95.00 \quad .000$

17. Dimanakah anak ibu bisa mendapatkan imunisasi?

$86.67 \quad 100.0 \quad .004$

18. Siapa saja yang mendapatkan imunisasi dasar?

$80.00 \quad 96.67 \quad .006$

Total

$62.16 \quad 96.26 \quad .000$

\section{Gambaran Pengetahuan dan Sikap Ibu Tentang Imunisasi Saat Sebelum dan Setelah Promosi Kesehatan}

Nilai rerata sikap ibu-ibu sebelum promosi kesehatan tentang imunisasi dasar adalah 3.01 yang berarti masuk ke dalam kategori dengan jawaban rata-rata menjawab setuju. Rerata sikap ibu sesudah promosi kesehatan adalah 3.03 yang berarti ibu-ibu menjawab setuju. Dari data tersebut didapatkan bahwa terdapat perbedaan yang signifikan dalam sikap ibu tentang imunisasi dasar antara sebelum dan sesudah promosi kesehatan dengan nilai $p=0.00$. 
Tabel 7. Gambaran sikap ibu sebelum dan sesudah promosi kesehatan

\begin{tabular}{ccccc}
\hline NO & Pertanyaan & $\begin{array}{c}\text { Mean } \\
\text { sebelum }\end{array}$ & $\begin{array}{c}\text { Mean } \\
\text { sesudah }\end{array}$ & Sig \\
\hline
\end{tabular}

1. Saya setuju dengan adanya program $\begin{array}{llll}\text { imunisasi dasar lengkap. } & 2.73 & 3.16 & .000\end{array}$

2. Saya akan memberikan imunisasi $\mathrm{BCG}$ $\begin{array}{llll}\text { pada anak untuk mencegah penyakit TBC. } & 2.61 & 3.16 & .000\end{array}$

3. Saya akan memberikan imunisasi Hepatitis $\begin{array}{llll}\text { B pada anak untuk mencegah penyakit } & 2.96 & 3.16 & .039\end{array}$ Hepatitis B

4. Saya akan memberikan imunisasi DPT pada anak untuk mencegah penyakit Difteri, Batuk 100 hari (Batuk rejan), dan Tetanus.

$2.88 \quad 3.13 \quad .018$

5. Saya akan memberikan imunisasi Polio pada anak untuk mencegah penyakit Polio.

$\begin{array}{lll}3.01 & 3.16 \quad .038\end{array}$

6. Saya akan memberikan imunisasi campak pada anak untuk mencegah penyakit Campak.

$3.03 \quad 3.16 \quad .073$

7. Saya merasa takut bila anak diimunisasi.

$\begin{array}{lllll}\text { 8. Anak saya memerlukan imunisasi BCG. } & 2.98 & 3.15 \quad 017\end{array}$

9. Anak saya memerlukan imunisasi Hepatitis B.

10. Anak saya memerlukan imunisasi combo DPT-HB I.

11. Anak saya memerlukan imunisasi Combo DPT-HB II

12. Anak saya memerlukan imunisasi Combo DPT-HB III.

13. Anak saya memerlukan imunisasi Polio I. 
Samuel: Peningkatan Pengetahuan dan Sikap Ibu

14. Anak saya memerlukan imunisasi Polio II. $\quad 2.98 \quad 3.15 \quad 040$

15. Anak saya memerlukan imunisasi Polio III. $\quad 3.05 \quad 3.15 \quad .135$

16. Anak saya memerlukan imunisasi Polio IV. $\quad 3.05 \quad 3.15 \quad .135$

17. Anak saya memerlukan imunisasi Campak. $\quad 2.98 \quad 3.15 \quad .040$

18. Saya bersedia membantu petugas kesehatan $\begin{array}{lllll}\text { untuk memberi informasi mengenai } & 2.95 & 3.15 & .004\end{array}$ program imunisasi dasar lengkap.

19. Saya bersedia bila anak saya mengikuti program imunisasi dasar lengkap walaupun jarak ke puskesmas/ Posyandu jauh.

$3.01 \quad 3.15 \quad .088$

Total

$3.01 \quad 3.03 \quad .000$

\section{Pembahasan}

Alasan yang melatarbelakiangi masih banyaknya bayi belum mendapatkan imunisasi dasar lengkap adalah karena alasan informasi, situasi dan motivasi. Alasan informasi berupa kurangnya pengetahuan ibu tentang kebutuhan, kelengkapan dan jadwal imunisasi, ketakutan akan imunisasi dan adanya persepsi salah yang beredar di masyarakat tentang imunisasi. Alasan motivasi berupa penundaan imunisasi, kurangnya kepercayaan tentang manfaat imunisasi dan adanya rumor buruk tentang imunisasi. Alasan situasi berupa tempat pelayanan imunisasi yang terlalu jauh, jadwal pemberian imunisasi yang tidak tepat, orangtua yang terlalu sibuk, adanya masalah dengan keluarga, anak yang sakit, terlalu lama menunggu dan biaya yang tidak terjangkau. Namun yang paling berpengaruh adalah karena ketidaktahuan ibu akan pentingnya imunisasi, ketidaktahuan ibu waktu yang tepat untuk mendaptkan imunisasi berikutnya dan ketakutan akan efek samping imunisasi (Depkes, 2014).

Pengetahuan ibu sangat berperan dalam pemberian imunisasi pada anak, oleh karena itu maka diperlukan promosi kesehatan tentang imunisasi dasar pada anak. Program imunisasi bertujuan untuk menurunkan angka kesakitan dan kematian dari penyakit yang dapat dicegah dengan imunisasi diantaranya adalah difteri, tetanus, batuk rejan (pertusis), campak (measles), polio, dan tuberculosis. Tingkat pengetahuan ibu yang rendah dapat dicegah dengan pemberian 
penyuluhan tentang imunisasi dasar. Penyuluhan tersebut harus mencakup semua hal yang berhubungan dengan imunisasi terutama tentang jadwal pemberian (Atika dan Eryati, 2015). Sriwahyuni (2015) menyatakan bahwa pemberian pendidikan kesehatan tentang imunisasi efektif terhadap peningkatan pengetahuan ibu tentang imunisasi.

Aspek pengetahuan ibu-ibu di desa Sukajaya tentang imunisasi dasar yang didapati terendah saat sebelum promosi kesehatan adalah tentang "Frekuensi pemberian imunisasi Hepatitis B" yaitu dalam kategori kurang (20,00). Pengetahuan ibu-ibu tentang frekuensi pemberian imunisasi hepatitis B tersebut kemudian berubah dan meningkat menjadi $(96,67)$ sangat baik setelah pemberian promosi kesehatan.

Aspek sikap ibu-ibu terhadap imunisasi dasar yang nilainya terendah sebelum pemberian promosi kesehatan adalah "saya akan memberikan imunisasi BCG” yaitu dalam kategori setuju $(2,61)$. Aspek sikap tersebut kemudian meningkat menjadi kategori setuju yang tinggi $(3,16)$ saat setelah diberikannya promosi kesehatan tentang imunisasi dasar. Keterlibatan pemuka agama sebagai tokoh masyarakat merupakan jembatan antara sektor kesehatan sebagai pelaksana program kesehatan dengan masyarakat (penerima program) kesehatan. Azwar (2013) menuliskan bahwa konsep moral dan ajaran dari lembaga pendidikan dan lembaga agama sangat menentukan sistem kepercayaa tidaklah mengherankan jika pada gilirannya konsep tersebut mempengaruhi sikap.

Keleher, et.al, (2007) menekankan bahwa promosi kesehatan memungkinkan individu untuk meningkatkan derajat kesehatannya. Termasuk di dalamnya adalah sehat secara fisik, mental dan sosial sehingga individu atau masyarakat dapat merealisasikan cita-citanya, mencukupi kebutuhan-kebutuhannya, serta mengubah atau mengatasi lingkungannya.

\section{Simpulan}

Kegiatan pelayanan masyarakat melakukan promosi kesehatan tentang imunisasi dasar pada ibu yang memiliki batita menunjukkan secara signifikan efektif meningkatkan pengetahuan dan sikap ibu terhadap imunisasi dasar. Promosi kesehatan merupakan esensi dari peran perawat yang secara nyata memberikan dampak yang positif dalam upaya meningkatkan peran serta masyarakat dalam meningkatkan derajat kesehatan batita khususnya, masyarakat dan bangsa 
Samuel: Peningkatan Pengetahuan dan Sikap Ibu

secara umum. Keterlibatan tokoh agama dalam masyarakat menjembatani penerimaan masyarakat terhadap program kesehatan.

\section{Ucapan Terimakasih}

Tim pelayanan masyarakat merasakan bahwa seluruh rencana dan pelaksanaan pelayanan msyarakat ini tidak akan dapat terlaksana dengan baik tanpa peran serta dan dukungan doa dan moral dari berbagai pihak. Ucapan terimakasih kami sampaikan kepada Ibu Hani bidan desa, Ibu Dedeh, Ibu Enung, Ibu Liani, Ibu Wiwin, Ibu Ane, dan Ibu Inge selaku Kader RW.06 desa Sukajaya yang telah membantu dan memberi ijin kepada Penulis untuk melaksanakan pelayanan masyarakat dan penelitian. Tim juga menyampaikan terimakasih kepada tokoh desa Bapak $\mathrm{H}$. Dadang Supriatna dan Ibu Hj. Hasanah Samastuti, para civitas akademika Fakultas Keperawatan Universitas Advent Indonesia, serta mahasiswa kami yang kreatif dan berdedikasi dalam menyusun alur acara dan memfasilitasi segala perlengkapan dengan baik diantaranya Virginia Gracella, Siti Aulia Hasanah, Nita Marlina, Dewi Kristiana, dan Willy Ferdiana.

\section{Daftar Pustaka}

Arifin, (2011). Hubungan Tingkat Pengetahuan Ibu Tentang Pentingnya Imunisasi Dasar dengan Kepatuhan Melaksanakan Imunisasi di Bps Hj. Umi Salamah di desa Kauman, Peterongan, Jombang

Atika Putri Dewi, Eryati Darwin, Edison (2014). Hubungan Tingkat Pengetahuan Ibu dengan Pemberian Imunisasi Dasar Lengkap pada Bayi di Kelurahan Parupuk Tabing Wilayah Kerja Puskesmas Lubuk Buaya Kota Padang Tahun 2013. Jurnal Kesehatan Andalas. Vol.3, No. 2.

Depkes.2017, bersama tingkatan cakupan imunisai menjaga anak tetap sehat, Yogyakarta, Indonesia.

Dewi Nur Intan Sari, Sri Wahyu Basuki, N.Juni Triastuti (2016). The Correlation Between Mother's Knowledge About Basic Immunization And Completeness Of Basic Baby Immunization in Puskesmas Bendo District Magetan. Biomedika, Vol.8, No. 2.

Dinas Kesehatan provinsi Jawa Barat, (2016). Profil Kesehatan Provinsi Jawa Barat, hal 114.

Friedrickson,D.D. Davis, T.C., Arnold, C.L Kennen, E.M., Humiston, S.G., Cross, T.J. 2004. Childhood Imunization Refusal : Provider and parent Perceptions. Family Medicine. 36(6) : 431-439. 
Samuel: Peningkatan Pengetahuan dan Sikap Ibu

Ikatan Dokter Anak Indonesia (IDAI) (2018). Buku Ajar Respirologi anak, edisi pertama. Jakarta: Badan Penerbit Ikatan Dokter Anak Indonesia.

Ikatan Dokter Anak Indonesia (IDAI). (2018). Seputar Pekan Imunisasi Dunia.

Keleher, H., MacDougall, C., at all, B. 2007. Understanding Health Promotion. Victoria, Australia : Oxford University Press.

Kementrian Kesehatan .RI. (2014) Buku Ajar Imunisasi. Jakarta: Pusat Pendidikan dan Pelatihan Tenaga Kesehatan

Kepmenkes, 2010. Gerakan Akselerasi Imunisasi Nasional Universal Child Imunization 20102014, Jakarta: Menteri Kesehatan.

Macintosh J.L.B., Eden L.M., Luthy K.E., Schouten A.E. (2017). Global Immunizations: Health Promotion and Disease Prevention Worldwide. MCN Am J Matern Child Nurs. 42(3):139145 .

Mahayu, P. (2014). Imunisasi dan Nutrisi. Jogjakarta : Buku Biru

Pos Kota News (Rabu, 4 Oktober, 2017). Pencapaian imunisasi MR di Depok terendah di Jawa Barat. (http://poskotanews.com/2017/10/04/pencapaian-imunisasi-mr-di-depokterendah-di-jawa-barat/.) Diakses 18 Desember, 2018.

Pratiwi, F. (2015). Faktor-Faktor Yang Mempengaruhi Ketidakpatuhan Ibu Terhadap Pelaksanaan Imunisasi Dasar Pada Balita.

WHO (2017). Global immunization coverage. Geneva :World Health Organization. 